\title{
Production of Obionin A and Derivatives by the Sooty Blotch Fungus Microcyclospora malicola
}

Authors

Affiliations
Frank Surup ${ }^{1,2}$, Ajda Medjedovic ${ }^{3}$, Hans-Josef Schroers ${ }^{3}$, Marc Stadler ${ }^{1,2}$

${ }^{1}$ Helmholtz Centre for Infection Research, Department of Microbial Drugs, Braunschweig, Germany

${ }^{2}$ German Centre for Infection Research (DZIF), Partner Site Hannover-Braunschweig, Braunschweig, Germany

${ }^{3}$ Agricultural Institute of Slovenia, Ljubljana, Slovenia
Key words

- Microcyclospora malicola strain 1930

- sooty blotch and flyspeck

- plant disease

- microbial interactions

- secondary metabolites

- natural products

- structure elucidation received Dec. 28, 2014

revised February 19, 2015

accepted March 2, 2015

\section{Bibliography}

DOI http://dx.doi.org/

10.1055/s-0035-1545908

Published online April 9, 2015

Planta Med 2015; 81:

1339-1344 @ Georg Thieme

Verlag KG Stuttgart · New York ·

ISSN 0032-0943

\section{Correspondence}

Prof. Dr. Marc Stadler

Helmholtz Centre for Infection

Research

Department Microbial Drugs

Inhoffenstraße 7

38124 Braunschweig

Germany

Phone: + 4953161814240

Fax: + 4953161819499

marc.stadler@helmholtz-hzi.de

\section{Abstract \\ $\nabla$}

A multitude of sooty blotch and flyspeck fungi, mainly belonging to the Ascomycetes order Capnodiales, causes dark blemishes and flyspeck-like spots on apples worldwide. Different sooty blotch and flyspeck fungi can coexist in the same orchard and even on a single fruit. Our preceding experiments revealed an activity of Microcyclospora malicola strain 1930 against the anthracnose fungus Colletotrichum fioriniae in dual culture assays. Extracts of M. malicola strain 1930 showed a broad bioactivity against filamentous fungus Mucor hiemalis and gram-positive bacterium Bacillus subtilis. A bioactivity-guided isolation led to the identification of obionin A (1) as the main active principle. In addition to 1 , which

\section{Introduction}

\section{$\nabla$}

Various members of the Ascomycetes order Capnodiales are known to form mycelial mats or fruiting bodies on the surface of epicuticular wax layers of apples that result in dark, flyspeck-like spots and sooty blemishes [1]. Although these fungi do not cause fruit destructing diseases or rots, sooty blotch and flyspeck (SBFS) fungi cause substantial economic damages. Stored apples may desiccate earlier during storage, and apples with dark smudges and blemishes have a reduced market quality [2]. Although sooty blotch fungi have early been associated with different kinds of mycelial types, only three species were distinguished as causal agents until the end of the 20th century [3]. A single species only was accepted as the causal agent of flyspeck. This situation changed dramatically when polyphasic taxonomic studies incorporated DNA sequence-based species recognition concepts, with the help of which at least 60 SBFS fungi were distinguished and numerous new species and genera described [4-6]. was previously isolated from the marine fungus Leptosphaeria obiones, we isolated three derivatives. Metabolite 2 bears a keto function at C-6, besides the replacement of oxygen by nitrogen at position 10. Two more derivatives are adducts (3, 4) of acetone as work-up artifacts. Because obio$\operatorname{nin} A(\mathbf{1})$ and its derivative $\mathbf{2}$ showed cytotoxic effects and antifungal activities, we propose a role of these secondary metabolites in the antagonism between $M$. malicola and other apple colonizing sooty blotch and flyspeck fungi, other epiphytes, or apple pathogens competing for the same ecological niche.

Supporting information available online at http://www.thieme-connect.de/products

Although different SBFS species can co-occur in the same orchard and even on the same apple, details of how they interact between each other or to host substrata and other fruit pathogens are hitherto little understood. During inventory studies for SBFS fungi in Slovenia, we observed that juxtaposed colonies of different SBFS fungi were clearly separated from each other on field-collected apples and that a selected strain of Microcyclospora tardicrescens inhibited the colony growth of the fruit pathogen Colletotrichum fioriniae in dual culture tests [7]. Bioassay-guided fractionation and subsequent structure elucidation yielded trichothecolone acetate and its novel (S)-7-hydroxy derivative as active principles for the interaction between $M$. tardicrescens and $C$. fioriniae. In this follow-up publication, we describe the investigation of an isolate of another sooty blotch species, Microcyclospora malicola, and its production of a series of bioactive pigments. 


\begin{tabular}{|c|c|c|c|c|}
\hline & 1 & 2 & 3 & 4 \\
\hline 4 & 6.64 , brs & $7.57, \mathrm{~s}$ & $5.81, \mathrm{~s}$ & 6.64 , brs \\
\hline 6 & 6.59 , brs & & $6.38,5$ & 6.66 , brs \\
\hline 8 & 5.80 , brs & $7.96, \mathrm{~s}$ & $5.72, \mathrm{~s}$ & 5.91, brs \\
\hline \multirow[t]{2}{*}{11} & $5.20, d(13.4)$ & $9.37, \mathrm{~s}$ & $5.19, \mathrm{~m}$ & 6.27 , brs \\
\hline & $5.16, d(13.4)$ & & $5.10, \mathrm{~m}$ & \\
\hline $1^{\prime}$ & $2.55, \mathrm{~m}$ & $3.32, \mathrm{~m}$ & 2.50, dqd $(9.5,6.9,5.0)$ & $2.61, \mathrm{~m}$ \\
\hline \multirow[t]{2}{*}{$2^{\prime}$} & 1.72 , ddd $(14.0,10.0,4.5)$ & 1.99, ddd $(13.9,9.4,4.7)$ & 1.72 , ddd $(14.0,9.0,3.4)$ & $1.75, \mathrm{~m}$ \\
\hline & $1.15, \mathrm{~m}$ & 1.47, ddd $(13.9,8.7,5.4)$ & $1.13, \mathrm{~m}$ & $1.18, \mathrm{~m}$ \\
\hline $3^{\prime}$ & $1.41, \mathrm{~m}$ & $1.15, \mathrm{~m}$ & $1.42, \mathrm{~m}$ & $1.41, m$ \\
\hline \multirow[t]{2}{*}{$4^{\prime}$} & $1.37, \mathrm{~m}$ & $1.33, \mathrm{~m}$ & $1.37, \mathrm{~m}$ & $1.37, \mathrm{~m}$ \\
\hline & $1.23, \mathrm{~m}$ & $1.18, \mathrm{~m}$ & $1.22, \mathrm{~m}$ & $1.19, \mathrm{~m}$ \\
\hline $5^{\prime}$ & $0.92, \mathrm{t}(7.3)$ & $0.87, \mathrm{t}(7.5)$ & $0.92, \mathrm{~m}$ & $0.91, \mathrm{t}(7.0)[0.90]$ \\
\hline $6^{\prime}$ & $1.20, d(6.9)$ & $1.38, d(6.9)$ & $1.18, \mathrm{dd}(6.9,2.6)$ & $1.24, \mathrm{~d}(6.7)[1.23]$ \\
\hline $7^{\prime}$ & $0.95, d(6.5)$ & $0.96, d(6.5)$ & $0.95, \mathrm{dd}(6.7,1.9)$ & $0.96, \mathrm{~d}(6.4)[0.95]$ \\
\hline 3-OMe & $3.85, \mathrm{~s}$ & $4.09, \mathrm{~s}$ & $3.78, \mathrm{~s}$ & $3.83, \mathrm{~s}$ \\
\hline $1^{\prime \prime}$ & & & $3.42, s$ & $3.44, s$ \\
\hline $3^{\prime \prime}$ & & & $2.14, \mathrm{~s}$ & $2.14, \mathrm{~s}$ \\
\hline
\end{tabular}

Table 1 ' ${ }^{1} \mathrm{H} \mathrm{NMR}(700 \mathrm{MHz})$ data of metabolites 1-4 in $\mathrm{CD}_{3} \mathrm{OD}$. Data divergent for minor isomers are shown in square brackets.<smiles>CCC(C)CC(C)C=C1C=C2C=C(OC)OCC2=C1</smiles>

1<smiles>CCC(C)CC(C)C1=Cc2cc3c(c(O)c2CO1)C(=O)[C@](O)(CC(=O)[Hg])C(OC)=C3</smiles>

3<smiles>CCC(C)CC(C)c1cc2c(cn1)C(=O)c1c(cc(OC)c(O)c1O)C2=O</smiles>

2<smiles>CCC(C)CC(C)C1=Cc2cc3c(c(O)c2[C@@H](O)O1)C(=O)[C@](O)(CC(C)=O)C(OC)=C3</smiles>

4
Fig. 1 Compounds isolated from cultures of M. malicola 1930.

\section{Results and Discussion}

$\nabla$

M. malicola strain 1930 inhibited the growth of the fungal apple rot pathogen $C$. fioriniae [7]. In addition, cultures of $M$. malicola 1930 also exhibited bioactivity against the filamentous fungus Mucor hiemalis and the gram-positive bacterium Bacillus subtilis. To assess its potential for the production of secondary metabolites, M. malicola strain 1930 was incubated in a $200-\mathrm{mL}$ shake flask culture. Both ethyl acetate extracts of the culture filtrate and acetone extracts of the mycelium showing a red coloration possessed antifungal and antibacterial activities, indicative of a lipophilic molecule being responsible for the observed bioactivity. Fractionation of the combined crude acetone and ethyl acetate extracts by preparative HPLC with a subsequent bioassay revealed the presence of four red pigments, of which at least one was clearly associated with the bioactive principle. Its molecular formula of $\mathrm{C}_{21} \mathrm{H}_{24} \mathrm{O}_{5}$ was deduced from the pseudomolecular ion cluster $[\mathrm{M}+\mathrm{H}]^{+}$at $m / z$ 357.1701. The UV/Vis spectrum showed absorption maxima at 242, 298, and $468 \mathrm{~nm}$ and therefore indicated an extensive $\pi$-system. Proton NMR ( Table 1 ) and ${ }^{13} \mathrm{C}$ HSQC NMR spectra revealed the presence of three aromatic and two aliphatic methines, three methylenes, one methoxy, and three aliphatic methyls; a database search with above informa- tion within the Dictionary of Natural Products on DVD identified obionin A (1) ( Fig. 1) [8,9]. The scale-up of the fermentation was repeated at larger scale using the same fermentation time and monitoring of the growth by determination of the $\mathrm{pH}$ value and free glucose content, but the yields were much lower in the larger shake flasks. The reason for this observation remains unclear, since no extensive optimization of the procedure has so far been carried out. Nevertheless, from the fact that a very dense pigmentation of the agar media was observed, fermentation on solid substrates might be most favorable for the production of obionins by M. malicola.

Besides 1, three additional red pigments were isolated. The HRESIMS pseudomolecular ion peak cluster $[\mathrm{M}+\mathrm{H}]^{+}$at $\mathrm{m} / \mathrm{z}$ 370.1656 yielded a molecular formula of $\mathrm{C}_{21} \mathrm{H}_{23} \mathrm{NO}_{5}$ for the second red pigment. In the proton NMR spectrum, the signal of the oxygenated methylene was missing, and the three aromatic methines were shifted downfield to $\delta_{\mathrm{H}} 9.37,7.96$, and $7.57 \mathrm{ppm}$, indicating an electron-deficient heteroaromatic system. The ${ }^{1} \mathrm{H},{ }^{13} \mathrm{C}$ HMBC correlations from $\mathrm{H}-4$ to $\mathrm{C}-2, \mathrm{C}-3, \mathrm{C}-5, \mathrm{C}-6$, and $\mathrm{C}-$ 14, from $\mathrm{H}-8$ to $\mathrm{C}-6, \mathrm{C}-9, \mathrm{C}-1$ ', and $\mathrm{C}-12$, and from $\mathrm{H}-11$ to $\mathrm{C}-9$, $\mathrm{C}-7, \mathrm{C}-12$, and $\mathrm{C}-13$ established the structure of $\mathbf{2}$ as the 10 -aza6-oxo derivative of 1. 


\begin{tabular}{|c|c|c|c|c|}
\hline & 1 & 2 & $3^{a}$ & $4^{b}$ \\
\hline 1 & $180.8, \mathrm{C}$ & 151.2, C & 202.1, C & $202.2, C$ \\
\hline 2 & $178.3, \mathrm{C}$ & 143.0, C & $73.1, \mathrm{C}$ & $73.0, C$ \\
\hline 3 & 145.1, C & $154.3, \mathrm{C}$ & 161.2, C & 161.6, C \\
\hline 4 & $115.4, \mathrm{CH}$ & 105.7, CH & $98.8, \mathrm{CH}$ & 98.7, $\mathrm{CH}$ \\
\hline 5 & $137.3, \mathrm{C}$ & $125.9, \mathrm{C}$ & $141.0, C$ & $141.5, \mathrm{C}$ \\
\hline 6 & $118.6, \mathrm{CH}$ & 182.1, C & $113.7, \mathrm{CH}$ & 114.1, CH \\
\hline 7 & 145.1, C & 141.1, C & $143.2, \mathrm{C}$ & 141.7, C \\
\hline 8 & $101.5, \mathrm{CH}$ & $118.4, \mathrm{CH}$ & $101.3, \mathrm{CH}$ & $100.9, \mathrm{CH}$ \\
\hline 9 & $171.4, C$ & 175.1, C & 168.7, C & 164.2, C \\
\hline 11 & $56.2, \mathrm{CH}_{2}$ & 149.3, C & $64.1, \mathrm{CH}_{2}$ & $96.7, \mathrm{CH}$ \\
\hline 12 & $112.6, C$ & $126.4, C$ & $110.8, C$ & $111.2, \mathrm{C}$ \\
\hline 13 & $162.4, C$ & 188.6, C & 159.0, C & $161.5, C$ \\
\hline 14 & $112.2, \mathrm{C}$ & $113.2, \mathrm{C}$ & 109.7, C & 109.5, C \\
\hline $1^{\prime}$ & $38.1, \mathrm{CH}$ & $41.4, \mathrm{CH}$ & $37.9, \mathrm{CH}$ & 38.0, CH \\
\hline $2^{\prime}$ & $42.7, \mathrm{CH}_{2}$ & $45.1, \mathrm{CH}_{2}$ & $42.7, \mathrm{CH}_{2}$ & 43.5, $\mathrm{CH}_{2}$ \\
\hline $3^{\prime}$ & $33.7, \mathrm{CH}$ & $33.5, \mathrm{CH}$ & $33.6, \mathrm{CH}$ & $33.4, \mathrm{CH}$ \\
\hline $4^{\prime}$ & $31.0, \mathrm{CH}_{2}$ & $30.9, \mathrm{CH}_{2}$ & $31.0, \mathrm{CH}_{2}$ & $30.9, \mathrm{CH}_{2}$ \\
\hline $5^{\prime}$ & $11.6, \mathrm{CH}_{3}$ & $11.5, \mathrm{CH}_{3}$ & $11.7, \mathrm{CH}_{3}$ & 11.6, $\mathrm{CH}_{3}$ \\
\hline $6^{\prime}$ & $19.8, \mathrm{CH}_{3}$ & $22.0, \mathrm{CH}_{3}$ & $19.9, \mathrm{CH}_{3}$ & $20.4, \mathrm{CH}_{3}$ \\
\hline $7^{\prime}$ & $19.5, \mathrm{CH}_{3}$ & $19.4, \mathrm{CH}_{3}$ & $19.5, \mathrm{CH}_{3}$ & $19.5, \mathrm{CH}_{3}$ \\
\hline 3-OMe & $57.5, \mathrm{CH}_{3}$ & 57.0, $\mathrm{CH}_{3}$ & $56.1, \mathrm{CH}_{3}$ & $56.2, \mathrm{CH}_{3}$ \\
\hline $1^{\prime \prime}$ & & & $51.4, \mathrm{CH}_{2}$ & 51.3, $\mathrm{CH}_{2}$ \\
\hline $2^{\prime \prime}$ & & & $208.3, C$ & $208.0, C$ \\
\hline $3^{\prime \prime}$ & & & $30.1, \mathrm{CH}_{3}$ & $30.0, \mathrm{CH}_{3}$ \\
\hline
\end{tabular}

Table $2{ }^{13} \mathrm{C} \mathrm{NMR}(175 \mathrm{MHz})$ data of metabolites 1-4 in $\mathrm{CD}_{3} \mathrm{OD}$.

a Data divergent for the following signals in the minor isomer: 164.3 (C-9), 114.2 (C-6), 100.8 (C-8), 96.6 (C-11), 30.8 (C-4'); b Data divergent for the following signals in the minor isomer: 166.9 (C-9), 101.1 (C-8), 96.3 (C-11), 38.2 (C-1'), 42.4 (C-2'), 33.5 (C-3'), 30.9 (C$\left.4^{\prime}\right), 19.5\left(C-6^{\prime}\right), 18.9\left(C-7^{\prime}\right)$

The third red pigment had the molecular formula $\mathrm{C}_{24} \mathrm{H}_{30} \mathrm{O}_{6}$, which was deduced from its pseudomolecular $[\mathrm{M}+\mathrm{H}]^{+}$ion cluster at $m / z 415.2120$. Its UV/Vis spectrum showed a hypsocromic shift $(-94 \mathrm{~nm})$ to $374 \mathrm{~nm}$ in comparison to 1 . The proton NMR spectrum of $\mathbf{3}$ was highly similar to $\mathbf{1}$. However, additional methylene and methyl singlets were observed, and the carbon spectrum ( Table 2 ) confirmed the presence of an additional quaternary hydroxylated carbon $\left(\delta_{\mathrm{C}} 73.1 \mathrm{ppm}\right)$. The structure of $\mathbf{3}$ was assigned by ${ }^{1} \mathrm{H},{ }^{13} \mathrm{C}$ HMBC correlations; correlations from $\mathrm{H}_{2}-1$ " and $\mathrm{H}_{3}-3$ " to ketone $\mathrm{C}-2$ " identified a 2-ketopropyl side chain, which is connected to the quaternary hydroxylated carbon $\mathrm{C}-2$ as demonstrated by ${ }^{1} \mathrm{H},{ }^{13} \mathrm{C}$ HMBC correlations from $\mathrm{H}_{2}-1$ " to $\mathrm{C}-1$, C-2, and C-3.

Furthermore, pigment 4 was isolated and shown to have a molecular mass of $430 \mathrm{Da}$ since its [M - $\mathrm{H}^{-}$peak was observed at $\mathrm{m} / \mathrm{z}$ $429 \mathrm{u}$ in the ESIMS spectrum (negative mode). The molecular formula $\mathrm{C}_{24} \mathrm{H}_{30} \mathrm{O}_{7}$, which was deduced from its $\left[\mathrm{M}+\mathrm{H}-\mathrm{H}_{2} \mathrm{O}\right]^{+}$peak in the HRESIMS spectrum, indicated the existence of an additional oxygen atom compared to 3 . The proton and carbon NMR spectra of $\mathbf{4}$ were nearly identical to that of $\mathbf{3}$. The key difference was the replacement of the methylene signal of C-11 by a methine. Its deep field chemical shift $\left(\delta_{C} 96.7\right)$ indicated the binding of two oxygen atoms. Consequently, compound 4 was identified as the 11-hydroxy derivative of compound 3 . Because signals of multiple carbons are split, we concluded a mixture of the C-2 and C-9 epimers.

Notably, compounds 3 and 4 are formed by the addition of acetone and are thus considered as artifacts rather than genuine natural products. An analogous degradation has been observed for the very closely related metabolite leptosphaerodione (5), a natural product of the marine ascomycete Leptosphaeria oraemaris. In the original study, the genuine secondary metabolite $\mathbf{5}$ was only obtained by the reconversion of the acetone adduct with
(i-Pr) $)_{2} \mathrm{EtN}$ in $\mathrm{CHCl}_{3}$ [9]. To avoid the conversion of natural pigments with acetone, the acetone was omitted as the solvent for the extraction procedure.

To obtain more material of metabolites 1 and 2, M. malicola 1930 was cultivated in a 2-L scale. The titers observed were lower than in the previous fermentation. However, $2 \mathrm{mg}$ of $\mathbf{1}$ and $0.5 \mathrm{mg}$ of $\mathbf{2}$ were isolated and tested for biological activity. The bioactivity of 1 was evaluated by determining their minimal inhibitory concentrations (MIC) against a broad test panel of bacteria and fungi ( Table 3). It showed good activities against various test strains of fungi and moderate activities against gram-positive bacteria. In a proliferation assay against the mouse fibroblast cell line L929, moderate cytotoxic effects were determined for $\mathbf{1}\left(\mathrm{IC}_{50}=\right.$ $7.6 \mu \mathrm{M})$ and $2\left(\mathrm{IC}_{50}=21 \mu \mathrm{M}\right)$.

Previously, obionin A (1) was isolated based on the brine shrimp toxicity of the crude extract of the marine fungus Leptosphaeria obiones, though the authors accentuate that $\mathbf{1}$ did not account for that activity [9]. However, we found moderate cytotoxicity for all pigments including 1, suggesting that cytotoxic effects may have been overlooked by Poch et al. [10], probably because of the low water solubility of the natural product. Obionin B (6) ( Fig. 2), a decaketide from an unidentified fungus of the order Pleosporales, has the same core structure as 1 but bears an $n$ heptyl chain instead of the saturated dimethylpentyl side chain of 1. For obionin B (6), moderate cytotoxic effects have been described against several human cancer cell lines including MCF-7 (breast carcinoma), NCI-H460 (large cell lung carcinoma), SF268 (astrocytoma), HT-29 (colorectal adenocarcinoma), and MDA-MB-435 (melanoma) cell lines [11]. A related pair of o-pyranonaphtoquinones [12], laccaridiones A (7) and B (8), was reported as promising antimycotic lead structures because of their inhibition of $C$. albicans adhesion to both epithelial and endothetial cells in a dose-dependent manner and their ability to sup- 


\begin{tabular}{|c|c|c|c|}
\hline Tested organism & 1 & 2 & Ref., b, c \\
\hline Chromobacterium violaceum DSM 30191 & 1 & 1 & $1.0^{\mathrm{a}}$ \\
\hline Escherichia coli DSM 1116 & 1 & 1 & $1.0^{\mathrm{a}}$ \\
\hline Micrococcus luteus DSM 20030 & 8.3 & 67 & $2.1^{\mathrm{a}}$ \\
\hline Mycobacterium diernhoferi DSM 43524 & 8.3 & 1 & $\leq 0.25^{\mathrm{a}}$ \\
\hline Nocardioides simplex DSM 20130 & 16.6 & n.t. & $16.6^{\mathrm{a}}$ \\
\hline Nocardia sp. DSM 43069 & 8.3 & n.t. & $0.25^{\mathrm{a}}$ \\
\hline Paenibacillus polymyxa DSM 36 & 1 & n.t. & $6.7^{\mathrm{a}}$ \\
\hline Pseudomonas aeruginosa DSM 50071 & 1 & 1 & $67^{b}$ \\
\hline Staphylococcus aureus DSM 346 & 8.3 & I & $\leq 0.25^{\mathrm{a}}$ \\
\hline Aspergillus clavatus DSM 816 & 33.3 & n.t. & $2.1^{\mathrm{c}}$ \\
\hline Candida albicans DSM 1665 & 1 & 1 & $4.2^{c}$ \\
\hline Hormoconis resinae DSM 1203 & 1 & n.t. & $<0.25^{c}$ \\
\hline Mucor hiemalis DSM 2656 & 8.3 & 1 & $2.1^{c}$ \\
\hline Nematospora coryli DSM 6981 & 8.3 & n.t. & $3.3^{c}$ \\
\hline Penicillium capsulatum DSM 2210 & 1 & n.t. & $16.6^{c}$ \\
\hline Pichia anomala DSM 6766 & n.i. & 1 & $4.2^{c}$ \\
\hline Rhodotorula glutinis DSM 10134 & 16.6 & 1 & $0.52^{c}$ \\
\hline Schizosaccharomyces pombe DSM 70572 & 16.6 & 1 & $33.3^{c}$ \\
\hline Trichosporon oleaginosus DSM 11815 & 33.3 & n.t. & $1.0^{c}$ \\
\hline
\end{tabular}

MIC values are given in ug/mL; (/) Indicates lack of activity; (n. t.) indicates not tested; a Oxytetracycline hydrochloride (1 mg/mL); ${ }^{\text {van- }}$ comycin $(5 \mathrm{mg} / \mathrm{mL}) ;{ }^{c}$ gentamycin $(10 \mathrm{mg} / \mathrm{mL}) ;{ }^{\circledR}$ nystatin $(1 \mathrm{mg} / \mathrm{mL})$

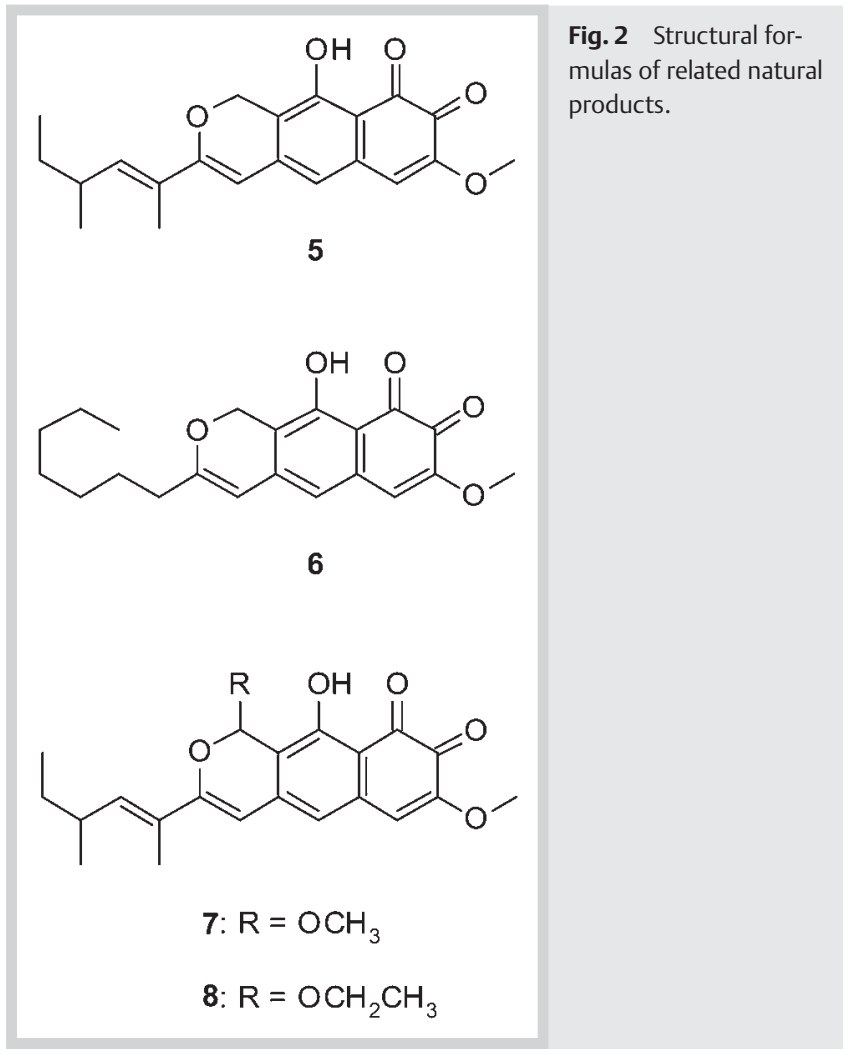

press the release and the inhibition of the catalytic activity of secreted aspartic proteases [13]. These effects resulted in reduced virulence properties (e.g., colonization and penetration of host tissues) without $\mathbf{7}$ and $\mathbf{8}$ being neither fungistatic nor fungicidal at the concentrations applied. Furthermore, laccaridione B (8) had an $\mathrm{IC}_{50}$ of $4.5 \mu \mathrm{M}$ for the K-562 human erythroleukemia, respectively, and $34 \mu \mathrm{M}$ for HeLa cervical carcinoma cells.

The biological activity of leptosphaerodione (5), the 1',2'-didehydro derivative of $\mathbf{1}$, had also been evaluated in in vitro assays. Me- tabolite $\mathbf{5}$ showed weak antibacterial effects against the gramnegative bacteria Escherichia coli $\mathrm{K} 12$ and Erwinia carotivora, but no gram-positives were tested in this study. Antimycotic activity was observed against Pythium ultimum 67-1, Fusarium graminearum GZ 3639, and Trichoderma atroviride P1 [14]. The production of $\mathbf{5}$ is tightly linked to the inhibitory ability of the producing fungus Stagonospora sp. on bindweeds; the amounts of 5 , as well as that of elsinochrome A, detected in extracts of culture filtrates of Stagonospora isolates by HPLC correlated with the aggressiveness of the isolates on bindweed species Convolvulus arvensis (field bindweed) and Calystegia sepium (hedge bindweed). This observation suggests an important role of $\mathbf{5}$ in the phytotoxic activity of Stagonospora [15].

Taken together, pyranonaphtoquinone metabolites 1-8 showed antifungal and cytotoxic effects in various test assays. The broad antimycotic acitivity of obionin A ( 1 ) and its derivative 2 implies that these metabolites are produced by M. malicola 1930 to inhibit the growth of coexisting fungi such as SBFS fungi, epiphytes, or apple pathogens.

Most known SBSF fungi are slowly growing species and apparently specifically adapted to inhabit the epicuticular wax of fruits. They may require the production of antifungal metabolites for competition. Because of their species richness, they present an ecological group ideal for studying bioactive natural products.

\section{Materials and Methods}

$\nabla$

\section{General experimental procedures}

Optical rotations were determined with a model 241 MC polarimeter (Perkin-Elmer). IR spectra were measured with a Spectrum 100 FTIR spectrometer (Perkin-Elmer); UV spectra were recorded with a UV-2450 UV-Vis spectrophotometer (Shimadzu). NMR spectra were recorded with an Ascend 700 spectrometer (Bruker Biospin) equipped with a 5 -mm TXI cryoprobe $\left({ }^{1} \mathrm{H}\right.$ $700 \mathrm{MHz},{ }^{13} \mathrm{C} 175 \mathrm{MHz}$ ). ESI-MS spectra were obtained with an Amazon ion trap mass spectrometer (Bruker Daltonik); HRESIMS spectra were obtained with a Maxis time-of-flight mass spec- 
trometer (Bruker Daltonik), both combined with a 1200 series HPLC-UV/Vis system (Agilent) [column $2.1 \times 50 \mathrm{~mm}, 1.7 \mu \mathrm{m}, \mathrm{C}_{18}$ Acquity UPLC BEH (Waters), solvent $\mathrm{A}: \mathrm{H}_{2} \mathrm{O}+0.1 \%$ formic acid; solvent B: $A C N+0.1 \%$ formic acid, gradient: $5 \%$ B for $0.5 \mathrm{~min}$ increasing to $100 \%$ B in $19.5 \mathrm{~min}$, maintaining $100 \%$ B for $5 \mathrm{~min}$, flow rate $0.6 \mathrm{~mL} \cdot \mathrm{min}^{-1}$, UV detection $200-600 \mathrm{~nm}$ ] combined with an ESI-TOF-MS (Maxis, Bruker) (scan range 100-2500 m/z, rate $2 \mathrm{~Hz}$, capillary voltage $4500 \mathrm{~V}$, dry temperature $200^{\circ} \mathrm{C}$ ). Test compounds and internal controls for the bioassays were checked by HPLC-MS and showed over $95 \%$ purity.

\section{Isolation of fungal strains, dual culture tests,}

bioactivity-guided fractionation

The techniques are described in previous publications $[6,7]$.

\section{Cultivation of Microcyclospora malicola strain 1930, preparation of crude extracts, and compound isolation by preparative HPLC}

Initial screening cultivation: Small pieces from well-grown PD agar plates were used to inoculate $200 \mathrm{~mL}$ YMG medium contained in two $250 \mathrm{~mL}$ Erlenmeyer flasks. These flasks were incubated on a rotary shaker at $25^{\circ} \mathrm{C}$ and $140 \mathrm{rpm}$. A color change to red was observed after 17 days. After 20 days, the cultures were harvested; the mycelium was separated from the fluid by filtration. The culture filtrate was extracted two times with ethyl acetate $(200 \mathrm{~mL}$ each). The wet mycelium was extracted with acetone in an ultrasonic-bath at $30^{\circ} \mathrm{C}$ for $30 \mathrm{~min}$. These extracts were analyzed by HPLC-MS, combined and filtered through an SPE C18 cartridge. The crude material $(47.4 \mathrm{mg})$ was fractionated by preparative RP HPLC (column $250 \times 21 \mathrm{~mm}$, VP Nucleodur C18 Gravity $5 \mu \mathrm{m}$, acetonitrile-water gradient $10 \%$ to $100 \% \mathrm{MeCN}$ in $30 \mathrm{~min}$, flow $15 \mathrm{~mL} / \mathrm{min}$ ) and provided $0.5 \mathrm{mg}$ of $\mathbf{1}, 0.4 \mathrm{mg}$ of $\mathbf{2}$, $0.3 \mathrm{mg}$ of 3 , and $0.3 \mathrm{mg}$ of 4 . The metabolites were eluted at $31.8-32.2,27.5-27.8,25.8-26.2$, and $27.8-28.5 \mathrm{~min}$, respectively. Upscale cultivation: M. malicola was cultivated and worked up as described above. However, four $5 \mathrm{~L}$ flasks containing $1.25 \mathrm{~L}$ of YMG medium were utilized, and the mycelium was extracted twice with $500 \mathrm{~mL}$ methanol. Preparative RP HPLC (column $250 \times 21 \mathrm{~mm}$, VP Nucleodur C18 Gravity $5 \mu \mathrm{m}$, acetonitrile-water gradient $60 \%$ to $85 \% \mathrm{MeCN}$ in $30 \mathrm{~min}$, flow $15 \mathrm{~mL} / \mathrm{min}$ ) provided $2.0 \mathrm{mg}$ of $\mathbf{1}$ and $0.5 \mathrm{mg}$ of $\mathbf{2}$.

Obionin A (1): Red oil, $[\alpha]_{\mathrm{D}}^{25}+70\left(c 0.01, \mathrm{CHCl}_{3}\right)$; UV (MeOH) $\lambda_{\max }$ $228 \mathrm{~nm}, 298 \mathrm{~nm}, 468 \mathrm{~nm}$; ${ }^{1} \mathrm{H}$ NMR (700 MHz, $\mathrm{CDCl}_{3}$, see $\odot$ Table 1; ${ }^{13} \mathrm{C}$ NMR (175 MHz, $\mathrm{CDCl}_{3}$ ), see $\odot$ Table 2; ESIMS $m / z 357.15$ $[\mathrm{M}+\mathrm{H}]^{+}, 355.17[\mathrm{M}-\mathrm{H}]^{-}$; HRESIMS m/z 357.1701 [M + H] $]^{+}$(calcd. for $\left.\mathrm{C}_{21} \mathrm{H}_{25} \mathrm{O}_{5}, 357.1697\right)$. Spectroscopic and spectrometric data are in good agreement with the literature [9].

8,9-dihydroxy-7-methoxy-3-(4-methylhexan-2-yl)benzo[g]isoquinoline-5,10-dione (2): Red oil; UV (MeOH) $\lambda_{\max } 240,290,424 \mathrm{~nm}$; ${ }^{1} \mathrm{H}$ NMR (700 MHz; $\mathrm{CDCl}_{3}$, see Table $1 ;{ }^{33} \mathrm{C} \mathrm{NMR}(175 \mathrm{MHz}$, $\mathrm{CDCl}_{3}$ ), see $\odot$ Table 2; ESIMS $m / z 370.12[\mathrm{M}+\mathrm{H}]^{+}, 368.09[\mathrm{M}-$ $\mathrm{H}]^{-}$; HRESIMS $m / z$ 370.1656 $[\mathrm{M}+\mathrm{H}]^{+}$(calcd. for $\mathrm{C}_{21} \mathrm{H}_{24} \mathrm{NO}_{5}$, 370.1649).

Compound 3: Orange oil; UV (MeOH) $\lambda_{\max } 256 \mathrm{~nm}, 374 \mathrm{~nm} ;{ }^{1} \mathrm{H}$ NMR (700 MHz; $\mathrm{CDCl}_{3}$, see $\odot$ Table $1 ;{ }^{13} \mathrm{C} \mathrm{NMR} \mathrm{(175} \mathrm{MHz}, \mathrm{CDCl}_{3}$ ), see $\bigcirc$ Table 2; ESIMS $m / z 415.18[\mathrm{M}+\mathrm{H}]^{+}, 413.15[\mathrm{M}-\mathrm{H}]^{-}$; HRESIMS $m / z$ 415.2120 $[\mathrm{M}+\mathrm{H}]^{+}$(calcd. for $\mathrm{C}_{24} \mathrm{H}_{31} \mathrm{O}_{6}, 415.2115$ ).

Compound 4: Orange oil; UV (MeOH) $\lambda_{\max } 256 \mathrm{~nm}, 374 \mathrm{~nm} ;{ }^{1} \mathrm{H}$ $\operatorname{NMR}\left(700 \mathrm{MHz} ; \mathrm{CDCl}_{3}\right.$, see $\odot$ Table $1 ;{ }^{13} \mathrm{C} \mathrm{NMR}\left(175 \mathrm{MHz}, \mathrm{CDCl}_{3}\right.$ ), see Table 2; ESIMS $m / z 413.18\left[\mathrm{M}+\mathrm{H}_{-} \mathrm{H}_{2} \mathrm{O}\right]^{+}, 429.15[\mathrm{M}-\mathrm{H}]^{-}$; HRESIMS $m / z$ 413.1961 $\left[\mathrm{M}+\mathrm{H}_{-} \mathrm{H}_{2} \mathrm{O}\right]^{+}$(calcd. for $\mathrm{C}_{24} \mathrm{H}_{29} \mathrm{O}_{6}$, 413.1959).

\section{Biological assays}

Biological assays for the evaluation of antimicrobial and cytotoxic activities were performed as previously described [16]. The compounds were tested against the bacteria B. subtilis DSM 10, E. coli DSM 1116, and Staphylococcus aureus DSM 346, and the fungi $C$. fioriniae HJS 2018, Pichia anomala DSM 6766, C. albicans DSM 1665 and Saccharomyces cerevisiae DSM 1333. The concentration of the purified compounds was tested with $100,50,25,12.5,6.25$, $3.13,1.56$, and $0.78 \mu \mathrm{g} / \mathrm{mL}$. The criterion of MIC was defined as the lowest concentration showing no visible bacterial or fungal growth after $24 \mathrm{~h}$ incubation.

\section{Supporting information}

UV, HRESIMS and ${ }^{1} \mathrm{H},{ }^{13} \mathrm{C}, \mathrm{COSY}, \mathrm{HSQC}$, and HMBC NMR spectra of metabolites 1-4 are available as Supporting Information.

\section{Acknowledgements}

We thank Michael Szczygielski for initial screening and isolation efforts, our colleagues Wera Collisi along with Bettina Hinkelmann for conducting the bioassays, Christel Kakoschke for recording NMR spectra, and Philine Wotsch for expert technical assistance in the mycological laboratory at HZI. For measurements of HPLC-MS data, we are grateful to Aileen Teichmann and Heinrich Steinmetz. Last but not least, the help of students and trainees Brigitta Balling, Yvonne Siebken, Kirsten Ullmann, Dorian Czerner, Yasmin Wenzel, and Haiyang Qin is acknowledged. Support of COST Action FA1103, allowing A.M. to join the HZI Braunschweig for a Short-Term Scientific Mission (STSM) in autumn of 2012 is also gratefully acknowledged.

\section{Conflict of Interest}

$\nabla$

The authors declare no competing financial interests.

\section{References}

1 Williamson SM, Turner SB. Sooty blotch and flyspeck of apple: etiology, biology, and control. Plant Dis 2000; 84: 714-724

2 Gleason ML, Batzer JC, Sun GY, Zhang R, Díaz Arias MM, Sutton TB, Crous $P W$, Ivanović M, McManus PS, Cooley DR, Mayr U, Weber RWS, Yoder KS, Del Ponte EM, Biggs AR, Oertel B. A new view of sooty blotch and flyspeck. Plant Dis 2011; 95: 368-383

3 Johnson EM, Sutton TB, Hodges CS. Etiology of apple sooty blotch disease in North Carolina. Phytopathology 1997; 87: 88-95

4 Díaz Arias MM, Batzer JC, Harrington TC, Wong AW, Bost SC. Diversity and biogeography of sooty blotch and flyspeck fungi on apple in the eastern and midwestern United States. Phytopathology 2010; 100: 345-355

5 Batzer JC, Gleason ML, Harrington TC, Tiffany LH. Expansion of the sooty blotch and flyspeck complex on apples based on analysis of ribosomal DNA gene sequences and morphology. Mycologia 2005; 97: 12681286

6 Frank J, Crous PW, Groenewald JZ, Oertel B, Hyde KD, Phengsintham P, Schroers HJ. Microcyclosporella and Microcyclospora: novel genera accommodating epiphytic fungi causing sooty blotch on apple. Persoonia 2010; 24: 93-105

7 Surup F, Medjedović A, Szczygielski M, Schroers HJ, Stadler M. Production of trichothecenes by the apple sooty blotch fungus Microcyclospora tardicrescens. J Agric Food Chem 2014; 62: 3525-3530

8 Anonymous. In: Buckingham J, editor. Dictionary of Natural Products on DVD. London: Chapman \& Hall, CRC; 2014

9 Guerriero A, D'Ambrosio M, Cuomo V, Pietra F. A novel, degraded polyketidic lactone, leptosphaerolide, and its likely diketone precursor, leptosphaerodione. Isolation from cultures of the marine ascomycete 
Leptosphaeria oraemaris (Linder). Helv Chim Acta 1991; 74: 14451450

10 Poch GK, Gloer JB. Obionin A: A new polyketide metabolite from the marine fungus Leptosphaeria obiones. Tetrahedron Lett 1989; 30 : 3483-3486

11 Ayers S, Graf TN, Adcock AF, Kroll DJ, Shen Q Swanson SM, Wani MC, Darveaux BA, Pearce $\mathrm{CJ}$, Oberlies $\mathrm{NH}$. Obionin B, an o-pyranonaphthoquinone decaketide from an unidentified fungus (MSX 63619) from the order Pleosporales. Tetrahedron Lett 2011; 52: 5128-5130

12 Berg A, Reiber K, Dörfelt H, Walter G, Schlegel B, Gräfe U. Laccaridones A and B, new protease inhibitors from Laccaria amethystea. J Antibiot 2000; 53: 1313-1316

13 Falkensammer B, Pleyer L, Ressler S, Berg A, Borg-von Zepelin M, Nagl M, Lass-Flörl C, Speth C, Dierich MP, Würzner R. Basidiomycete metabolites attenuate virulence properties of Candida albicans in vitro. Mycoses 2008; 51: 505-514

14 Boss D, Maurhofer M, Schläpfer E, Défago G. Elsinochrome A production by the bindweed biocontrol fungus Stagonospora convolvuli LA39 does not pose a risk to the environment or the consumer of treated crops. Plant Pathol 2007; 59: 194-205

15 Ahonsi MO, Maurhofer M, Boss D, Défago G. Relationship between aggressiveness of Stagonospora sp. isolates on field and hedge bindweeds, and in vitro production of fungal metabolites cercosporin, elsinochrome A and leptosphaerodione. Eur J Plant Pathol 2005; 111: $203-$ 215

16 Surup F, Mohr KI, Stadler M. Cohaerins G.-K., azaphilone pigments from Annulohypoxylon cohaerens and absolute stereochemistry of cohaerins C-K. Phytochemistry 2013; 95: 252-258 